\title{
O COLÉGIO MARISTA NO CONTEXTO DA URBANIZAÇÃO DE CASCAVEL, PARANÁ (1962-1989).
}

\author{
Francielle Aparecida Garuti de Andrade ${ }^{1}$ \\ Cézar de Alencar Arnaut de Toledo ${ }^{2}$ \\ Universidade Estadual de Maringá
}

\section{RESUMO}

A presente pesquisa situa-se no campo da História e Historiografia das Instituições Educacionais e tem como objetivo reconstituir a história e a memória da implantação do Colégio Marista de Cascavel, fundado no ano de 1962, no contexto da migração para o oeste paranaense e da urbanização do município de Cascavel. Trata-se de uma pesquisa histórica e documental, sua realização se deu por meio da análise de documentos que descrevem a trajetória da instituição, bem como suas atividades e sua relevância no cenário educacional de Cascavel. As atividades educacionais do Colégio Marista de Cascavel tiveram início em 24 de março de 1962, com a chegada dos Irmãos Carlos Leone, Hermenegildo Alzola e Norberto José. A reconstituição da história do Colégio Marista de Cascavel serviu para explicitar as características da educação escolar ofertada na década de 1960 na região, bem como trouxe à tona as políticas educacionais brasileiras do período e as particularidades da modalidade de ensino técnico-profissional. A pesquisa permitiu constatar que a educação oferecida pela instituição contribuiu para a formação e manutenção da elite pioneira local.

Palavras-chave: História da Educação; Instituições Escolares; Colégio Marista de Cascavel.

\section{THE MARIST SCHOOL IN THE CONTEXT OF URBANIZATION OF CASCAVEL, PARANÁ (1962-1989).}

\begin{abstract}
This research is in the field of History and Historiography of Educational Institutions, and aims to reconstruct the history and memory of the implantation of the Marist School from Cascavel, founded in 1962 in the context of migration to the west of Paraná and urbanization of Cascavel City. This is a historic and documentary research. Its realization was through the analysis of documents that describe the trajectory of the institution, as well its activities and its relevance in the educational scenario of Cascavel City. The educational activities of the Marist School from Cascavel began on March 24th, 1962, with the arrival of the Brothers Carlos Leone, Hermenegildo Alzola and Norberto José. The reconstitution of the history of Marist School from Cascavel helps to explain the characteristics of the education offered in the 1960s in the region, and brings out the Brazilian educational policies of the period and the characteristics of professional technical education mode. The research allowed to find that the education offered by the institution contributed to the formation and maintenance of local pioneer elite.

Keywords: History of Education; Educational Institutions; Marist School from Cascavel.
\end{abstract}




\section{Introdução}

Este texto tem como objeto de investigação o Colégio Marista de Cascavel, implantado no ano de 1962 no contexto da migração para o oeste paranaense e da urbanização do município de Cascavel. A filosofia educacional do Colégio é de orientação Católica Romana, pois a instituição é vinculada à Congregação Religiosa dos Irmãos Maristas.

Trata-se de um estudo histórico e documental sobre a implantação dessa instituição educativa. Para tanto, inicialmente será analisado o conceito de instituições escolares e seu desenvolvimento como uma Linha de Pesquisa no interior do campo da História da Educação, bem como a importância da questão teórica e metodológica para as pesquisas sobre a temática. Em seguida, será apresentado o panorama sócio-político da região oeste do Paraná e a fundação da cidade de Cascavel nesse contexto; será destacado também o processo de urbanização e o consequente aumento da demanda por educação escolar que se deu no município no período. Por fim, será analisada a implantação do Colégio Marista em Cascavel, e os elementos constitutivos de sua fundação.

A pesquisa se situa no campo da História da Educação e os dados revelados pelas fontes foram analisados à luz da literatura sobre instituições escolares e relacionados às condições sociais do contexto político e econômico em que foram produzidos. No estudo sobre o Colégio Marista de Cascavel propomos uma análise que busca relacionar a instituição com a sociedade, partindo de um contexto mais amplo para um mais específico, ocupando-nos em apresentar as peculiaridades dentro da totalidade histórica, uma vez que o singular (escola) não existe por si mesmo, pois está contido no universal e, o universal por sua vez, não está separado das contraditórias relações das múltiplas singularidades.

O Colégio Marista de Cascavel é uma importante instituição escolar da rede privada de ensino, criada para atender uma nova demanda por escolas, que se deu na região na década de 1960. Suas atividades tiveram início em 24 de março de 1962, com a chegada dos Irmãos Carlos Leone, Hermenegildo Alzola e Norberto José, todos vinculados à Congregação dos Irmãos Maristas. Inicialmente a escola funcionou num prédio construído em madeiras, onde era o Ginásio Rio Branco e a Escola Técnica de Comércio, por isso, quando dos Atos de transferência de estabelecimento, o Ginásio Rio Branco passou a ser Colégio Marista de Cascavel e a Escola Técnica de Comércio passou a ser o Colégio Comercial Marista de Cascavel, ambas conexas.

Quanto à delimitação temporal, optamos pelo recorte do ano de 1962, período em que tiveram início as atividades da instituição, até 1989, quando o ensino técnicoprofissional cessou suas atividades no contexto pós-ditadura civil militar.

$\mathrm{Na}$ elaboração do trabalho, foi buscada a literatura sobre instituições escolares e sobre a História da Educação brasileira, que serviu como base teórica para historiar o processo de implantação do Colégio em Cascavel. No processo de reconstituição histórica dessa instituição educativa, procuramos investigar a escola a partir de sua relação com a sociedade que a produziu e não como um fenômeno isolado.

Para a efetivação da pesquisa foram utilizadas fontes como: Anais do Colégio Marista de Cascavel (1962-1986); Atas das atividades pedagógicas e administrativas da instituição; Atas da Câmara Municipal de Cascavel; Escritura pública de doação e permuta de terreno; Documentos da Secretaria Estadual de Educação para a autorização e funcionamento dos cursos diversos; Documentos de aprovação do projeto de implantação da escola; Documentos sobre a filosofia educacional e a pedagogia Marista; Cartas de Marcelino Champagnat sobre a questão educacional; Estatutos da Congregação dos Irmãos Maristas; Autorização da Província Marista Centro-Sul para a abertura do Colégio em 
Cascavel; Fotos históricas; Recortes de Jornal da época da implantação da instituição, entre outras. As fontes para pesquisa foram coletadas em diferentes locais e instituições, a saber: acervo do Colégio Marista de Cascavel; arquivo da Casa Geral dos Maristas, em Roma; Museu da Imagem e do Som de Cascavel; Casa Geral da Província Centro-Sul em Curitiba; acervos da Câmara Municipal de Cascavel; Biblioteca Municipal de Cascavel; Leis municipais de Cascavel.

\section{Instituições escolares no contexto da História da Educação brasileira: questão metodológica}

A história da educação, enquanto disciplina, tem sua trajetória diretamente associada ao curso de Pedagogia, que se desenvolveu inicialmente em alguns países da Europa e nos Estados Unidos. A disciplina apareceu nas universidades europeias no final do século XIX para atender à necessidade de um ensino sistemático da pedagogia. No Brasil, a disciplina desenvolveu-se, sobretudo, nas escolas do chamado Normal e outros cursos de formação de professores. Historicamente a História da Educação foi apresentada como disciplina de grande importância no processo de construção das Ciências da Educação em meados do século XIX, com a função de legitimação da própria passagem da Pedagogia ao estatuto de Ciências da Educação (GATTI JÚNIOR, 2007).

A temática que analisa a história e a historiografia das instituições educativas surgiu no contexto da História da Educação, principalmente a partir da década de 1990. Partindo da premissa de que a análise de uma instituição educativa poderia oferecer subsídios que serviriam para a compreensão do fenômeno educativo em sua totalidade; assim, o campo da História da Educação passou a contemplar os estudos sobre a escola (MAGALHÃES, 2010). Ancorados na possibilidade de que por meio do estudo da história e das práticas educativas de uma instituição seria possível conhecer importantes aspectos da história da educação brasileira, muitos pesquisadores atualmente têm se lançado nessa tarefa.

No Brasil, a análise sobre a história das instituições escolares tem se firmado como uma Linha de Pesquisa no âmbito da História da Educação e se constituído cada vez mais, num campo de investigação promissor. A possibilidade de se escrever a história da educação brasileira e regional sob um prisma diferente daquele que dá espaço apenas às narrativas emanadas de documentos oficiais tem sido um importante elemento motivador para as investigações sobre a história das instituições escolares. É uma proposta de pesquisa que visa à valorização das peculiaridades regionais, sem desconsiderar as dimensões nacionais; entende-se que ao analisar as características de uma determinada instituição, espacial e geograficamente determinada, nasce a possibilidade de conhecer o contexto histórico-político e social que a criou (SAVIANI, 2007; ARNAUT DE TOLEDO, ANDRADE, 2013).

Para o estudo da história de uma instituição educativa, há que voltar-se para o próprio conceito de instituição, que está diretamente ligado à atividade do homem, pois ela é produto da ação humana. Ela é voltada a atender as necessidades presentes. A palavra instituição guarda a ideia comum de algo que não estava dado, mas, que foi criado, posto, organizado, constituído pelo homem e apresenta-se como uma estrutura material, constituída para atender às necessidades permanentes. Segundo Dermeval Saviani, o termo origina-se do latim institutio, onis, e apresenta uma variação de significados, podendo caracterizar-se como sendo: plano, disposição, ordenação, instrução, criação, método e /ou sistema. Pode-se dizer, portanto, que as instituições surgem para atender necessidades permanentes, pois necessidades passageiras, de caráter conjuntural, são normalmente 
atendidas sem necessidade de se recorrer a atividades institucionalizadas (SAVIANI, 2013).

A análise da trajetória histórica das instituições escolares é um meio pelo qual que se pode entender um determinado contexto e um período histórico, pois a escola é organizada para responder às necessidades da sociedade, muito embora, seja ela mesma, objeto de contradições, de lutas, de embates e de proposições de superação da ordem vigente; é nisso que reside à contradição da educação, pois ela recebe influência do seu entorno, mas, ao mesmo tempo o influencia (CURY, 1985). A relação existente entre a escola e a sociedade é conflituosa, pois os grupos sociais opostos lutam em favor de escolas que atendam aos interesses que lhe são próprios. Por isso, a criação e o desenvolvimento de uma instituição educativa estão condicionados pela sociedade que, igualmente, é influenciada por ela.

A conexão íntima entre a sociedade e a escola por ela criada, adquire tamanha envergadura que passa a interferir nas relações de produção, moldando-as conforme os interesses das classes sociais. Assim, a instituição educativa cumpre funções específicas, está sempre ideologicamente influenciada e politicamente comprometida. As instituições educativas são constituídas por uma prática social e histórica cujas representações são interiorizadas no processo educativo, trazendo à luz, em cada contexto e momento histórico, ações destinadas a atender os interesses da sociedade para a qual foram pensadas e organizadas (NOSELLA; BUFFA, 2012).

Os sistemas educacionais institucionalizados são esferas cujas condições históricas retratam dados que contribuem para a reconstituição da memória de uma determinada sociedade; nesse sentido, as pesquisas sobre instituições escolares podem contribuir para aclarar as questões relativas à relação entre sociedade e educação, no movimento da história, numa análise de fora para dentro, ou seja, da sociedade para o interior da escola (SANFELICE, 2009).

O estudo das instituições escolares não é uma área restrita do conhecimento, mas sim, um recorte do campo da História da Educação. O recorte serve para destacar o objeto para que este, seja mais bem analisado, jamais apara isolá-lo. A instituição escolar, na perspectiva de José Luís Sanfelice é "particular com identidade própria, mas com capacidade para relacionar-se com o universal de maneira a não ensimesmar-se" (SANGELICE, 2010, p. 14). Nesse sentido, a história das instituições escolares é história da própria educação, pois toda parte se relaciona com o todo e, a análise da história de uma instituição, pode ser a chave para se compreender a educação no sentido mais geral. "Se considero que na História da Educação o tema-objeto central é a educação, a história de instituições escolares constitui-se em um dos seus possíveis recortes monográficos" (SANFELICE, 2002, p.40).

Nos estudos sobre essa temática, a questão metodológica apresenta-se como de fundamental importância para os resultados da pesquisa, pois se trata de uma tarefa epistemológica. Entendemos que no processo de reconstituição histórica de uma instituição educativa, o pesquisador deve partir do concreto-dado. O concreto, levado a efeito, é a totalidade. Na perspectiva de Karl Marx, a melhor forma de iniciar a análise de um objeto é partir do real e do concreto, que são as condições prévias e efetivas para, depois de reflexões mais aprimoradas, de abstrações complexas, atingir o concreto real. $\mathrm{O}$ percurso de análise passa, então, de um todo não desenvolvido para um todo mais desenvolvido.

É também lícito dizer que a categoria mais simples pode exprimir relações dominantes de um todo não desenvolvido ou relações 
subordinadas de um todo mais desenvolvido que já existiam historicamente antes de esse todo se desenvolver por esse lado expresso numa categoria mais concreta. Em tal medida, a marcha do pensamento abstrato, ao se elevar do mais simples ao complexo, corresponderia ao processo histórico efetivamente real (MARX, 1996, p. 13).

No entanto, faz-se necessário distinguir o concreto-dado do concreto-pensado. $\mathrm{Na}$ perspectiva de Marx, esse processo é resultado da faculdade de abstrair com base em categorias. $\mathrm{O}$ processo de pesquisa deve iniciar a partir da abstração de categorias mais simples, e por abstrações contínuas e progressivas, cada vez mais complexas, chegar-se ao concreto-pensado, no resultado. O método analítico é produto de uma elaboração teóricocientífica sincrética e substancial, elaborada em um processo de sucessivas e complexas aproximações do objeto de análise. Para Marx, o sentido de abstração se dá mediante a capacidade intelectiva de extrair de um determinado contexto, um elemento, isolá-lo e examiná-lo. No percurso analítico, a abstração retira do elemento abstraído a sua realidade mais concreta, tornando-o abstrato, porém, carregado de determinações múltiplas e por isto, "unidade do diverso" que é própria de toda totalidade (MARX, 1983).

O conhecimento teórico é um constructo da realidade, "cientificamente exato" e que se consubstancia em um concreto-pensado, produzido e reproduzido de modo dialético, numa "viagem de modo inverso", isto é, um retorno ao concreto-dado. Com efeito, o método consiste em elevar-se do concreto-dado ao concreto-pensado, da abstração à síntese, meio este pelo qual o homem enquanto ser social se apropria do mundo (NETTO, 2009).

$\mathrm{Na}$ investigação da história e da historiografia das instituições educacionais, o pesquisador deve seguir um plano de pesquisa analítico que parta da sociedade para a escola, das múltiplas determinações que influenciaram a sua constituição, para que, então, possa traçar uma leitura da instituição com seus atores, aspectos de sua organização, seu cotidiano, seus rituais, sua cultura e seu significado para a sociedade. De posse dos conceitos fundamentais do método de análise, o pesquisador pode estabelecer uma conexão coerente entre escola e sociedade. Essa relação dialética entre escola e sociedade será entendida a partir do levantamento e da análise de qualquer dado empírico da instituição escolar como, documentos, fotografias, plantas, cadernos ou livros didáticos (SANFELICE, 2007).

$\mathrm{Na}$ realização de pesquisas sobre instituições escolares o pesquisador pode seguir um roteiro de análise que considere o contexto histórico da criação e da instalação da escola; seu processo evolutivo: origens, apogeu e situação atual; o cotidiano escolar; o prédio e infraestrutura escolar: organização do espaço, estilo, acabamento, implantação, reformas e eventuais descaracterizações; corpo discente: origem social, destino profissional e suas organizações; corpo docente e equipe pedagógica: origem, formação, atuação e organização; organização pedagógica: currículo, disciplinas, livros didáticos, métodos e instrumentos de ensino; práticas disciplinares: regimentos, organização do poder, burocracia, prêmios e castigos; eventos: festas, exposições, desfiles (BUFFA, 2002; NOSELLA, BUFFA, 2009).

Toda instituição, escolar ou não, faz parte do todo social, de uma complexa rede de relações sociais concretas, cujas determinações formam um sistema societário integral e em constante transformação, sendo produzida pelo movimento histórico formado com base na luta entre elementos societários contraditórios; todavia, ela possui elementos internos que a difere de outras instituições, fazendo-a única e que são revelados por meio da singularidade. Por esse motivo, toda pesquisa precisa ir além da aparência do objeto, deve 
revelar não apenas o movimento presente dos fenômenos, mas também, como estes se reproduzem e se transformam (BITTAR; FERREIRA Jr, 2009; GOHN, 2005). Na medida em que a pesquisa avança e o processo de ampliação do conhecimento se inicia, passa-se, então, a revelar o que há de universal no particular.

Numa palavra: o método de pesquisa que propicia o conhecimento teórico, partindo da aparência, visa alcançar a essência do objeto. Alcançando a essência do objeto, isto é: capturando a sua estrutura e dinâmica, por meio de procedimentos analíticos e operando a sua síntese, o pesquisador a reproduz no plano do pensamento; mediante a pesquisa, viabilizada pelo método, o pesquisador reproduz, no plano ideal, a essência do objeto que investigou (NETTO, 2009, p. 674).

Ao estudar a história das instituições escolares, o pesquisador a retrata como reconstrução histórica, porque seu objeto, a escola, não resulta de uma construção sua, ela já existe e/ou existiu, o que ele, pesquisador, constrói é o conhecimento do objeto e isso significa reconstruí-lo no plano do pensamento (SAVIANI, 2007).

O processo de escrever a história das instituições escolares amplia as possibilidades de compreensão da própria História da Educação, na medida em que elas se relacionam com o todo, e não são mera subdivisão da Educação. O exercício de historiar as instituições educativas pode permitir o avanço no conhecimento sobre como a sociedade se organiza e transmite o conhecimento escolar com a finalidade de formar e informar o modelo de sujeito concebido por ela como ideal.

\section{3. $O$ contexto da ocupação e colonização do oeste paranaense}

O processo de colonização da região passou por vários períodos e fases. A primeira fase diz respeito à população autóctone, como Xetá, Kaigang e Guarani. A segunda está relacionada ao período em que os jesuítas se instalaram na região. A terceira fase data do período entre 1881 e 1930, e teve início com a introdução e consolidação do sistema obragero, que pretendeu explorar a madeira e a erva-mate. A quarta fase se refere à ocupação liderada pelas companhias colonizadoras. Todavia, foi no final do século XX, com a intensificação do processo de migração interna que se deu no país, que indivíduos oriundos especialmente da região sul, migraram para o oeste paranaense dando início ao processo de colonização planejada da região (PIAIA, 2004; GARUTI DE ANDRADE, 2016).

No final do século XIX e início do século XX, a região era pouco explorada. À época, algumas regiões do Paraná não haviam se integrado aos centros de decisão política e econômica do estado. Esse cenário mudou na medida em que a conquista e a ocupação de novas terras no oeste paranaense começaram a tomar amplas dimensões e companhias argentinas e inglesas se radicaram nessas terras, dando início à extração da madeira, da erva-mate e de outros produtos de origem agrícola (WACHOWICZ, 1982; SBARDELOTTO, 2009).

O processo de ocupação da região foi fomentado pelo projeto arquitetado pelo governo de Getúlio Vargas (1882 - 1954), denominado de Marcha para o Oeste. Com a intenção de nacionalizar as fronteiras do país, este programa federal contava com o apoio do governo estadual e do capital privado nacional. O movimento rumo ao oeste era de conquista, de expansão e objetivava a ocupação das regiões do país, que à época eram 
pouco exploradas pelo capitalismo comercial. Propunha-se um povoamento racional, para tanto, era necessário assumir uma ideologia de ocupação e povoamento das regiões de fronteira, o que significava uma retomada do ideal bandeirante, dos desbravadores que conquistaram, exploraram riquezas e ocuparam os "vazios demográficos" do país em séculos anteriores (BÔAS; BÔAS, 1994; BESKOW, 2007).

O Governo Vargas entendia ser necessário o desbravamento do campo para acelerar a industrialização, por isso as ações oficiais do Governo visavam sempre o fortalecimento do Estado e a integração do país. Nesse momento, o Nacionalismo passou a ganhar cada vez mais força. Medidas administrativas que fundiam os interesses de empresários e os interesses governamentais passaram a ser priorizadas e as regiões de fronteiras do país foram ocupadas mediante ostensiva atuação de empresas colonizadoras (LENHARO 1986; ARNAUT DE TOLEDO, ANDRADE, 2014).

A atuação das empresas colonizadoras, de capital privado, teve início a partir da década de 1940 e foram decisivas no processo de povoamento intensivo da região. Dentre as empresas colonizadoras que atuaram no oeste paranaense, podemos destacar as seguintes: Colonizadora Gaúcha Ltda. (São Miguel do Iguaçu); Industrial Agrícola Bento Gonçalves (Medianeira); Colonizadora Matelândia (Matelândia); Terras e Pinhais Ltda. (São Jorge - Foz do Iguaçu) e a Pinho e Terras Ltda. (Céu Azul) (COLODEL, 2003). O munícipio de Cascavel foi colonizado nesse contexto.

\subsection{O processo de urbanização e escolarização do munícipio de Cascavel}

O município de Cascavel está situado na região oeste do Paraná, a menos de 150 $\mathrm{km}$ das fronteiras do Brasil com a Argentina e o Paraguai e até o ano de 1881 essa área não havia sido explorada, era habitada por uma população autóctone da etnia Kaigang. O período de ocupação do território que hoje compreende o município de Cascavel não difere das demais regiões do oeste do Paraná que, devido à sua situação geográfica, política e econômica e, por localizar-se em região fronteiriça, passou a despertar a atenção das autoridades, que intensificaram o seu povoamento por meio de um programa de colonização. A ideia de ocupar a região oeste do Paraná foi viabilizada no final do Império, ano de 1888, e se estendeu no período da República, chegando ao seu ápice no governo de Getúlio Vargas (FAUTH, 1973; LENHARO 1986).

A ocupação e a colonização tanto da região, em geral, quanto do território de Cascavel, em particular, não se deu de modo amigável, foi marcado por litígios e violências comandadas por "jagunços". A colonização desenvolvida na região foi racional e intensiva. O modelo de colonização empresarial posto em prática representou a transição de um território considerado "sertão" para um espaço produtivo. Em nome do progresso da região, posseiros e grileiros foram expulsos de modo violento. Todo o percurso de exploração da terra foi marcado pela violência e pelo sangue, entendido e apresentado pelas autoridades envolvidas e interessadas no sucesso da colonização, como sinônimo de cultivo da terra e sede de progresso (PIAIA, 2013).

Conforme consta da documentação sobre a história de Cascavel, o ano de 1922 marcou o início da migração para região. Antônio José Elias, oriundo de Santa Catarina, foi o primeiro a solicitar ao estado uma propriedade rural considerada devoluta, que ficava às margens do rio Cascavel. A terra foi cedida e, nesse mesmo ano ele e seus familiares passaram a ocupar produtivamente a área. Nesse mesmo período, José Silvério de Oliveira, oriundo de Garapuava, também conhecido como "Nhô Jeca", prestador de serviço de limpeza dos ervais para as obrages ${ }^{3}$, visitou o local e decidiu se estabelecer na região com 
sua família, nos idos de 1930. Logo de início, "Nhô Jeca" passou a construir casas e instalou um comércio para atender aos viajantes e aos moradores locais, inclusive famílias de colonos poloneses que haviam se radicado na região e os trabalhadores das obrages; ele pode ser considerado o primeiro habitante a projetar a cidade (FAUTH, 1973; SPERANÇA, 1992).

Após Getúlio Vargas assumir a Presidência da República e pôr em prática seu plano nacionalista, José Silvério se empenhou em transferir o posto telegráfico de Lopei para Cascavel. $\mathrm{O}$ fato de o governo passar a exigir que empresas estabelecidas no território brasileiro tivessem, no mínimo, dois terços de funcionários brasileiros, contribuiu efetivamente para o desenvolvimento da região. No ano de 1931, Cascavel já era um povoado com um número considerável de habitantes e, em 1932, já contava com a sua primeira escola. Em pouco tempo Cascavel foi elevado à categoria de Distrito Administrativo do Município de Foz do Iguaçu, pelo Decreto Lei ${ }^{\circ} 7.573$ de 20 de outubro de 1938. Suas delimitações, à época, davam-se desde o Rio Iguaçu até a Foz do Rio Piquiri (PIAIA, 2013; SPERANÇA, 1992).

A construção da primeira escola no município de Cascavel se deu nesse contexto. A primeira iniciativa de institucionalização da educação no município aconteceu no ano de 1932, com a criação de uma escola nas dependências da Igreja Católica, chamada pelos moradores de "escolinha da igreja", que na verdade era uma instituição educativa que funcionava no modelo de Casa de Escolar $^{4}$ (EMER, 2012). Nos três primeiros anos de funcionamento, a escola era mantida pela população local. Os primeiros professores da escola foram: Orozendo Cordeiro de Jesus e as irmãs Genoveva e Estanislava Boiarski (EMER, 1991).

No ano de 1937, após a construção do aeroporto de Cascavel, a cidade passou a receber mais habitantes, muitos ligados à aviação e muitos outros com maior poder aquisitivo, fazendo com que a questão educacional ganhasse mais solidez e amplitude. Em 1938, foi criada a Casa de Escolar pública ${ }^{5}$, também foi o ano em que Cascavel foi elevada à categoria de distrito administrativo de Foz do Iguaçu. A partir do ano de 1947, a educação em Cascavel, ainda na condição de distrito de Foz do Iguaçu, foi estadualizada. O estado do Paraná passou a manter a escola e a pagar os professores (SPERANÇA; SPERANÇA, 1980).

Em 14 de novembro de 1951, Cascavel foi elevado à categoria de Município desmembrando-se do Município de Foz do Iguaçu e o Governador do Paraná Bento Munhoz da Rocha Neto sancionou a lei no 790/51 que criou o Município de Cascavel.

LEI $n^{\circ} 790 / 51$

DATA: $\quad 14 \quad$ DE $\quad$ NOVEMBRO $\quad$ DE 1951. SÚMULA: Dispõe sobre a divisão administrativa do Estado no quinquênio de 1952 a 1956.

Art. $1^{\circ}$. - A Assembleia Legislativa do Estado obedecerá, no quinquênio de 1952 a 1956 a composição constante dos quadros I e II, anexos que ficam fazendo parte integrante desta Lei. Art.2 ${ }^{\circ}$. - As novas unidades administrativas serão instaladas na data de posse dos respectivos Prefeitos. Art. $3^{\circ}$. - Dentro de noventa dias a contar da data de instalação, cada município publicará o ato estabelecendo os quadros urbanos e suburbanos das novas áreas municipais e distritais. Art. $4^{\circ}$. - Fica o Poder Executivo autorizado a contribuir com o auxílio de Cr\$100.000,00 (cem mil cruzeiros) a cada município criado mediante requerimento do respectivo prefeito. Parágrafo único: Este auxílio não se estende aos municípios de fronteira. Art. $5^{\circ}$. Esta Lei entrará em vigor na data de sua 
publicação, revogadas as disposições em contrário. Palácio do Governo em Curitiba, em 14 de novembro de 1951. Ass. Bento Munhoz da Rocha Neto (CURITIBA, 1951).

Com a criação do Município, a colonização de Cascavel foi intensificada. As concessões de terras aos colonos, feitas pelo Governo do estado do Paraná, tornou-se uma prática corriqueira neste período. Com isso, muitos colonos, de todas as regiões do Brasil, migraram para Cascavel a fim de tomar posse de qualquer área que estivesse desocupada. Nesse contexto, vieram também para Cascavel muitas empresas madeireiras, visando a extração da madeira, especialmente os pinheiros que, à época, existiam sobejamente na região (FAUTH, 1973).

O ano de 1953 foi importante para o avanço do município e para consolidação da rede escolar. Em virtude do rápido progresso, cascavel foi elevada a categoria de Comarca, por meio do Decreto Estadual n ${ }^{\circ} 1.542$ de 14 de dezembro de 1953. Nesse mesmo ano, em 23 de outubro, a Casa Escolar foi elevada à condição de Grupo Escolar ${ }^{6}$, e passou a ser gerido pelo município. Nesse período, sobretudo a partir da segunda metade da década de 1950, a educação escolar em Cascavel ganhou cada vez mais amplitude e investimentos, passando a receber novos estabelecimentos de ensino que contribuíram para o crescimento econômico da cidade de cascavel e de toda região, sendo que, alguns deles ainda hoje atuam na cidade: a Escola Normal Regional, o Colégio Auxiliadora, e o Colégio Rio Branco, hoje Colégio Marista (NATH, 2013; THOMÉ, 2005).

Há que destacar que o período imediatamente posterior à criação do município representou para Cascavel, uma importante transformação no cenário político-econômico e educacional, sendo a economia madeireira a principal responsável por esse impulso, em especial, no fim de 1950 e 1960. Os fatores econômicos e educacionais "andavam de mãos dadas", pois, ao mesmo tempo em que a economia crescia, crescia também a necessidade de mais escolas para os filhos dos colonos. Foi nesse contexto de avanço econômico, grande crescimento demográfico, urbanização e ampliação da rede escolar do município que o Colégio Marista foi criado (GARUTI DE ANDRADE, 2016).

O processo de urbanização de Cascavel teve início nos anos de 1960 e esteve diretamente relacionado à reestruturação e pavimentação da BR-277; antiga BR-35. A rodovia, chamada de Estrada Estratégica, dinamizou a economia do município, no âmbito do oeste paranaense, fomentando seu processo de urbanização. A cidade de Cascavel foi beneficiada com a BR-277, pois era bem localizada. Seu espaço geográfico permitia acesso tanto às fronteiras internacionais quanto à capital do estado, Curitiba (REOLON, 2007; PIAIA, 2004).

Após a década de 1960, Cascavel era considerada a cidade que mais crescia no Paraná e a quarta no Brasil. Entre as décadas de 1970 e 1980, o município já ultrapassava 100.000 habitantes, e já se enquadrava na categoria de município de médio porte. Cascavel passou por um rápido crescimento demográfico e econômico. Nesse contexto de amplo desenvolvimento e crescimento populacional, a procura por educação foi se tornando uma realidade cada vez mais presente, consequentemente, os investimentos do Poder Público eram cada vez mais urgentes (SPERANÇA, 1992; NATH, 2010).

Assim, devido ao crescimento populacional e a demanda por escolas, a década de 1960 representou um importante avanço não só para os setores da economia, mas também para o campo educacional no município de Cascavel. O Colégio Marista foi criado nessa conjuntura história para atender aos interesses de uma população que pretendia resolver o problema educacional de seus filhos e que ansiava por uma educação escolar diferenciada, que estivesse alicerçada em bases como: ensino de qualidade e proposta de formação 
integral do aluno. A filosofia educacional proposta pelo Colégio Marista atendia a essa demanda, por isso, com base nos dados revelados pelas fontes, podemos dizer que a implantação da instituição na cidade foi necessária para aquela sociedade, que encontrou no modelo educacional Marista, calcado em princípios éticos e valores cristãos, a escola que buscava.

\section{História da implantação do Colégio Marista em Cascavel (1962)}

Para analisar o Colégio Marista de Cascavel, foi necessário considerar o período e o contexto de sua criação na cidade (1962), integrá-lo no sistema educativo mais amplo, na comunidade e na região onde a instituição desenvolveu e desenvolve suas atividades, para compreender o movimento da história que a envolve e também "sistematizar-lhe e (re)escrever-lhe o itinerário de vida na sua multidimensionalidade, conferindo-lhe um sentido histórico" (MAGALHÃES, 1999, p. 64).

Ao mergulhar no interior da instituição, foi possível entender o contexto histórico de sua fundação, do seu desenvolvimento, de sua consolidação no cenário educacional de Cascavel e das alterações arquitetônicas pelas quais passou. Buscamos apreender o processo de formação da identidade de seus sujeitos (professores, gestores, alunos, técnicos) que por ela passaram no decorrer dos anos, as práticas pedagógicas que ali se realizaram e, sobretudo, o sentido de sua implantação na cidade num período de expansão e urbanização, que, nesta pesquisa, entendemos ser a questão de fundo (SANFELICE, 2006).

A partir da documentação disponível, podemos dizer que o Colégio Marista de Cascavel apresenta, em suas particularidades, informações que se relacionam com as questões locais, regionais, nacionais e até mesmo internacionais, pois seu método de ensino é norteado por uma filosofia cristã mundial, que é pautada pelos pressupostos católicos de Marcelino Champagnat (1789-1840), e empregados em cada país conforme seus ideais políticos de formar e manter uma estrutura hegemônica. Embora a filosofia marista seja a diretriz de sua prática pedagógica, os colégios se adaptam às necessidades locais, ou seja, articulam seus princípios às demandas de cada região; este se torna um fator que contribui para que os interesses da Igreja e do Estado se misturem. A educação proposta pelos colégios Maristas, a exemplo de outras instituições confessionais católicas, mantidas por diferentes ordens religiosas, tem o objetivo de "educar para a cidadania, formar bons cristãos", cidadãos cumpridores dos deveres cívicos e que respeitem a hierarquia social (MOURA, 2000; VIEIRA, 2007).

O Colégio Marista de Cascavel faz parte da Província Marista Brasil Centro-Sul, cuja sede administrativa é na cidade de São Paulo. Apesar de as escolas maristas terem diretorias locais próprias, elas estão subordinadas à Província e, são mantidas pela ABECAssociação Brasileira de Educação e Cultura, uma associação sem fins lucrativos que é sustentada por recursos derivados da contribuição de seus associados, da taxa semestral de cursos, de promoções de eventos, de doações e de trabalho voluntário. O Colégio Marista de Cascavel é uma instituição escolar que tem um significado social na cidade e na região, especialmente por conta de sua tradição e por refletir traços significativos da história da cidade em sua própria história (GARUTI DE ANDRADE, 2016).

As discussões acerca da implantação do Colégio Marista em Cascavel estiveram inseridas no contexto da Lei de Diretrizes e Bases da Educação Nacional (LDB), Lei $n^{\circ}$ 4024/61. Embora a Lei tenha sido sancionada em 1961, ela entrou em vigor no ano de 1962. A LDB teve como principal eixo temático o tratamento igualitário dos estabelecimentos de ensino da rede pública e privada, bem como o financiamento público 
para as instituições de ensino da rede privada e a formação de uma legislação única para a educação, fazendo valer os interesses da Igreja Católica para a manutenção e difusão dos seus ideais por meio do ensino (BRASIL, 1961).

O empenho pela vinda dos Irmãos Maristas para Cascavel partiu da administração do município, pois no contexto de rápido desenvolvimento econômico e aumento demográfico em que estava, era de interesse da cidade estruturar bases hegemônicas e mantê-las com uma educação que privilegiasse os filhos da nascente elite cascavelense, conforme a Lei N $292 / 64$, sancionada pelo Prefeito de Cascavel, Otacilio Mion (gestão de 14/12/60 a 14/12/64; 31/01/69 a 31/01/73), em 14 de setembro de 1964, que autorizou ao poder executivo transferir à $\mathrm{ABEC}$ todos os direitos relativos ao Ginásio Rio Branco (CASCAVEL, 1964).

A Educação Marista, no período, já era tradicionalmente conhecida em muitos países. Sua filosofia educacional preconizava que o papel de suas instituições escolares era o de "formar bons cristãos e virtuosos cidadãos". Os eixos centrais da Educação Marista sempre foram pautados pela Educação da Consciência, pela Educação da Inteligência e pela Educação da Vontade. Esse programa pedagógico era ideal para uma cidade em vias de expansão e urbanização. Segundo Alceu Sperança, em matéria publicada no jornal "O Paraná", em janeiro de 2006, sobre a história do Colégio Rio Branco, o primeiro contato entre José Neves Formighéri, à época prefeito de Cascavel (14/12/52 a 14/12/56), e o Superior Provincial (1953 a 1958), Irmão João de Deus, ocorreu em 28 de setembro de 1956 (SPERANÇA, 2006).

O incentivo por parte da cidade de Cascavel para a vinda dos Irmãos Maristas aconteceu por meio da doação de uma área de $71.000 \mathrm{~m}^{2}$, posteriormente Centro Esportivo Ciro Nardi, para a instalação da Instituição Marista e esforço particular do Bispo de Toledo, Dom Armando Círio. No entanto, foi proposta uma permuta da área doada por uma escola já instalada, o Ginásio Rio Branco. Estando as partes em acordo, no dia 22 de janeiro de 1962, o Ginásio Rio Branco passou a denominar-se Ginásio Marista de Cascavel e a Escola Técnica de Comércio, Colégio Comercial Marista de Cascavel, e naquele mesmo mês, no dia 27 de janeiro, iniciaram-se as reformas das instalações do prédio (COLÉGIO MARISTA DE CASCAVEL, 1962b).

Conforme consta da Ata, no dia 20 de janeiro de 1962, procedeu-se a cerimônia de transferência da Escola Técnica de Comércio Rio Branco, adquirida pela prefeitura de Cascavel do Sr. Antonio Cid, e concedida para a ABEC. Na cerimônia esteve presente o Prefeito da cidade; vereadores; o Pároco; o Bispo Diocesano de Toledo; o Presidente da ABEC; o antigo proprietário do estabelecimento, Antonio Cid; o diretor do Ginásio Marista e do Colégio Comercial Marista de Cascavel, Irmão Carlos Leone; o secretário, Irmão Hermenegildo Alzola; professores da instituição e seus familiares (COLÉGIO MARISTA DE CASCAVEL, 1962b).

No início das atividades em Cascavel, os primeiros irmãos responsáveis pela escola, fizeram um relatório detalhado de suas tarefas diárias e das primeiras ações educacionais do Colégio Marista na cidade. Conforme consta deste documento ${ }^{7}$, elaborado pelos Irmãos, num primeiro momento, até que a reforma do prédio que os abrigaria ficasse pronta, eles dormiam na casa canônica e se alimentava no Colégio Nossa Senhora Auxiliadora, mantido pela Ordem das Irmãs de São Carlos. Todavia, os Anais registram que a despeito das dificuldades iniciais, os Irmãos Maristas foram alocados nas dependências do recém-cedido Colégio, no dia 27 de janeiro daquele ano, antes mesmo de encerradas as reformas do Ginásio pela prefeitura. Segundo os relatos dos Irmãos, até que tudo fosse concluído, muitos reveses tiveram que ser enfrentados e superados. 
Nas nossas dependências, só tínhamos as camas e as roupas próprias. Nenhuma cadeira, armário ou qualquer outra coisa. Pulgas, baratas e ratos eram sem conta. $\mathrm{O}$ barulho da serraria bem ao lado e nossos cantos ora alegres, ora tristes, formavam um coro que terminava altas horas da noite e recomeçava às 4 horas da madrugada (COLÉGIO MARISTA DE CASCAVEL, 1962a, p. 2).

As aulas tiveram início no dia 8 de março de 1962 com 191 alunos matriculados, como consta do documento elaborado pelos Irmãos. Cruzando as fontes, notamos que há uma discrepância em relação ao número inicial de alunos. Embora, no sítio eletrônico do Colégio de Cascavel conste que a instituição iniciou suas atividades com o número de 350 alunos, nos Anais elaborados pelos Irmãos, consta o número inicial de 191 alunos matriculados e, no ano de 1963, é que consta o início as aulas com 350 alunos matriculados (COLÉGIO MARISTA DE CASCAVEL, 1962a).

Quando começaram as atividades da instituição, eram ofertados os cursos Ginasial, Técnico-Profissional e o Curso Primário. Os alunos matriculados nas primeiras turmas da modalidade de ensino primário não pagavam altas mensalidades, apenas contribuíam para o pagamento dos honorários dos professores. Esse princípio, contudo, foi modificado na medida em que a escola foi crescendo. No final do ano de 1964, ano do golpe militar, o Governo passou a custear cinco professoras para o curso primário no Colégio Marista, o que acabou propiciando a oficialização dessa modalidade, que passou a receber o nome de Escola Primária Champagnat, a datar de $1^{\circ}$ de março de 1965 (COLÉGIO MARISTA DE CASCAVEL, 1962a).

O crescimento do Colégio Marista se deu de modo acelerado, correspondentemente ao crescimento da cidade de Cascavel. No ano seguinte ao de sua implantação, a instituição praticamente dobrou seu número de alunos. No início do ano letivo, a quantia era de 350 alunos matriculados, sendo que somente o Curso Primário, recém-divulgado, já contava com um número significativo de alunos (COLÉGIO MARISTA DE CASCAVEL, 1962a). O quadro a seguir, elaborado com base nos dados disponíveis no acervo da instituição, demonstra o rápido desenvolvimento do Colégio Marista nos seus primeiros oito anos de funcionamento ${ }^{8}$.

Quadro 1 - Desenvolvimento do Colégio Marista entre os anos de 1962 a 1970.

\begin{tabular}{|l|l|}
\hline QUADRO DO DESENVOLVIMENTO DO COLÉGIO MARISTA (1962 A 1989). \\
\hline $\begin{array}{l}\text { Número de alunos matriculados nos cursos: } \\
\text { Primário, Ginasial e Técnico. }\end{array}$ & Ano correspondente \\
\hline 191 & 1962 \\
\hline 350 & 1963 \\
\hline 460 & 1964 \\
\hline 606 & 1965 \\
\hline$(\cong) 606$ & 1966 \\
\hline 620 & 1967 \\
\hline$\cong) 792$ & 1968 \\
\hline 840 & 1969 \\
\hline 950 & 1970 \\
\hline
\end{tabular}

Fonte: Acervo do Colégio Marista de Cascavel.

Verifica-se o rápido crescimento da demanda por vagas e o aumento de matriculas da instituição o que acabou contribuindo para sua consolidação como instituição educativa 
de qualidade e que participou dos rumos políticos, religiosos e sociais da cidade de Cascavel. O espaço social que o Colégio Marista possuía pode ser notado nos documentos históricos encontrados em seu acervo, como a participação da banda marcial nos eventos da cidade. Nos documentos da instituição, elaborado pelos Irmãos, por diversas vezes é feita menção às autoridades governamentais que sempre estavam presentes nas festividades político-religiosas de Cascavel e da região e, a presença dos Irmãos Maristas e dos seus discentes é sempre mencionada no sentido de que se faziam presentes para "abrilhantar" os festejos.

Dia 27 de junho de 1964 - inauguração da Caixa d'água Municipal. O Colégio esteve presente [...]. 12 de maio de 1965 - Cascavel teve a insigne honra e receber todos os bispos do Paraná conjuntamente. Nosso Colégio com grande satisfação cedeu suas dependências para a celebração de duas missas por dois deles. A fanfarra apresentou-se para abrilhantar as festividades organizadas em homenagem aos Príncipes da Igreja. [...] 14 de novembro de 1965 - Dia da cidade de Cascavel. Mais uma vez, o Colégio colaborou no brilhantismo das festas promovidas pela Prefeitura. [...] 30 de agosto de 1966 - Cascavel tem a insigne honra de receber o Embaixador Pontifício, o Núncio Apostólico, Sua Excia. Revma. D. Sebastião Baggio. S. Excia. Conversou demoradamente com os Irmãos, por ter sido capelão dos Maristas em El Salvador, na América Central. A cidade vibrou de alegria e o Colégio colaborou como sempre, nas festividades (COLÉGIO MARISTA DE CASCAVEL, 1962a).

Quando da criação do Colégio Marista de Cascavel, embora já existissem outras instituições de ensino na cidade, as famílias com maior poder aquisitivo e influência social optavam por matricular seus filhos na instituição, pois consideravam que o ensino por ela ofertado era de boa qualidade. O Colégio atendeu um público que possuía condições financeiras para custear as anuidades que os alunos deveriam pagar. Isso demostra que escola, desde sua implantação, era destinada para a formação de uma elite local (COLÉGIO MARISTA DE CASCAVEL, 1962a).

Em relação aos cursos oferecidos, o Colégio dispunha do curso Primário, Ginasial e Comercial, embasados na Lei 4.024/61. Entretanto, os cursos passaram por reformulações após a LDB de 1971. Apresentamos a seguir um quadro dos cursos que foram ofertados pelo Colégio nos anos subsequentes à sua implantação até a promulgação da Lei 5.692/71, quando houve ampliação da infraestrutura do Colégio e mudanças no seu currículo, por decorrência das novas características que a sociedade cascavelense foi adquirindo com as mudanças econômicas e demográficas.

Quadro 2 - Cursos ministrados pelo Colégio Marista desde sua fundação até a promulgação da LDB 5692/71.

\begin{tabular}{|c|c|c|}
\hline \multicolumn{3}{|c|}{$\begin{array}{l}\text { CURSOS MINISTRADOS PELO COLÉGIO MARISTA DESDE SUA FUNDAÇÃO ATÉ A } \\
\text { PROMULGAÇÃO DA LDB 5692/71 }{ }^{9} \text {. }\end{array}$} \\
\hline $\begin{array}{l}\text { Escola Champagnat } \\
\text { (Curso Primário) }\end{array}$ & $\begin{array}{l}\text { Ginásio Marista de Cascavel } \\
\text { (Curso Ginasial) }\end{array}$ & $\begin{array}{l}\text { Colégio Comercial Marista de } \\
\text { Cascavel } \\
\text { (Técnico profissionalizante) }\end{array}$ \\
\hline $\begin{array}{l}1965 \text { a } 1972-4^{\text {a }} \text { Séries } \\
\text { (decreto no } 20.362 \text { de } 30 \\
\text { de dezembro de } 1965 \text { ). }\end{array}$ & $\begin{array}{l}1962 \text { a } 1972-4^{\text {a }} \text { Séries (Ato de } \\
\text { alteração do nome }-n^{\circ} 5 \text { de } 27 \text { de } \\
\text { fevereiro de 1962). }\end{array}$ & $1962-1^{\mathrm{a}}$ e $2^{\mathrm{a}}$ Séries. \\
\hline $\begin{array}{l}1973-3^{\mathrm{a}} \text { e } 4^{\mathrm{a}} \text { Séries. } \\
\text { Após essa data todas as }\end{array}$ & $1973-2^{\mathrm{a}}, 3^{\mathrm{a}}$ e $4^{\mathrm{a}}$ Séries. & 1963 a $1974-3^{a}$ Séries. \\
\hline
\end{tabular}




\begin{tabular}{|l|l|l|}
\hline $\begin{array}{l}\text { Séries funcionaram } \\
\text { regularmente. }\end{array}$ & \\
\hline
\end{tabular}

Fonte: Acervo do Colégio Marista de Cascavel.

A partir do ano de 1973, o Colégio foi ampliando cada vez mais suas instalações. No mês de junho de 1990 foi inaugurado um ginásio poliesportivo com espaços destinados para atividades extraclasse, esportivas ou culturais. Mais uma vez para acompanhar o crescimento da cidade, a instituição inaugurou, em 24 de fevereiro de 2003, um novo prédio com instalações mais modernas. No evento de inauguração estiveram presentes autoridades Maristas e autoridades político-administrativas da cidade de Cascavel, como o Prefeito Edgar Bueno (01/01/09 a 31/12/12; 01/01/13 a 31/12/16), ex-aluno da instituição e o Arcebispo Dom Lúcio Ignácio Baumgaertner (COLÉGIO MARISTA DE CASCAVEL, 2003).

Ao se dispor a educar para o trabalho e para a cidadania, a educação escolar Marista, em se tratando do caso brasileiro, propõe uma pedagogia fundada na ética cristã, porém, por estar inserida num contexto político/econômico cuja matriz é capitalista, a pedagogia marista acaba sendo influenciada por esse sistema. Segundo Carlos Roberto Jamil Cury, ao defender a escola confessional, a Igreja Católica, defendia também um modelo de educação privado, diretamente relacionado a uma perspectiva capitalista. Este posicionamento pode ser notado nos debates ideológicos que resultaram na promulgação da Lei $\mathrm{n}^{\circ}$ 4.024/61, que, beneficiou diretamente as instituições educacionais da rede privada de ensino, por meio de subvenções (CURY, 1988).

Neste período, houve por parte da Igreja Católica um massivo investimento na criação e manutenção de escolas confessionais, pois a educação escolar constituía-se numa das principais estratégias da Igreja para influenciar de modo mais decisivo os rumos e as decisões da sociedade.

\subsection{Ensino técnico-profissionalizante nas décadas de 1960 a 1980}

No início do século XX o ensino técnico-profissional, especialmente, o ensino comercial era frequente nos estabelecimentos de ensino dos Irmãos Maristas. O Colégio Marista de Cascavel ofertava essa modalidade quando ainda não havia legislação específica que regulamentasse esse tipo de ensino. Contudo, ele estava ancorado por decretos-lei; por exemplo, as Leis Orgânicas do Ensino (1942 a 1946), fruto da reforma educacional do ministro Gustavo Capanema (1900-1985). Além do mais, por se tratar de uma cidade que estava em processo de desenvolvimento urbano, expansão industrial e agropecuária, era importante formar pessoas habilitadas para atuar na administração e no desenvolvimento local (TREVISAN, 2009; BRASIL, 1942).

A Lei $n^{\circ} 4.024 / 61$, mesmo que de modo não explícito, abordava a questão do ensino profissionalizante. Embora representasse uma modalidade destinada à classe popular, era a elite que desfrutava desse tipo de ensino, uma vez que se referia ao último nível de acesso à educação, equiparado ao ensino superior. A escola, nesse contexto, continuava ser um privilégio de classe (BRASIL, 1961).

A Lei de Diretrizes e Bases da Educação Nacional, Lei no 5.692/71, aprovada em 11 de agosto de 1971, no contexto da ditadura civil militar e em consonância aos interesses da sociedade capitalista, não revogou totalmente a Lei $n^{\circ}$ 4.024/61, mas, definiu a educação como preparação para o trabalho, tanto no $1^{\circ}$ como no $2^{\circ}$ grau. Por determinação dessa Lei, as modalidades de ensino: Secundário, Normal, Técnico Industrial, Técnico Comercial e o 
Agro-técnico, deviam ser todos equiparados. Todos os estabelecimentos educacionais deveriam ofertar cursos profissionalizantes (BRASIL, 1971; SAVIANI, 1983).

O objetivo da reforma do ensino instituída pela Lei 5.692/71, no período da ditadura, tinha, dentre os objetivos, o de conter o avanço das ideias progressistas consideradas de esquerda e, reprimir o movimento operário. Visava ainda, ofertar qualificação mínima aos trabalhadores em geral, institucionalizar e restringir a formação técnico-profissional, para favorecimento da produção do capital esperado pela burguesia nacional e conservar o status quo (SAVIANI, 2008).

A formação para o mercado de trabalho é apresentada de modo explícito na Lei 5.692/71, dado seu caráter tecnicista. Nela foi destacado, dentre outros critérios, o desenvolvimento individual, a formação profissional, o exercício da cidadania e a importância de uma educação integral. A Lei, na teoria, parecia ser direcionada à população proletária, porém, suas características, na prática, não incluíam os jovens da classe trabalhadora (BRASIL, 1971; XAVIER; et al., 1994).

Com o fim da ditadura civil militar, em meados da década de 1980, o país passou por reformulações no campo político e econômico. Recessões na economia e altas taxas de inflação faziam com que mudanças ocorressem no campo educacional. O controle de verbas e o critério na distribuição dos recursos foram algumas das medidas tomadas pelo governo federal em relação à educação. Esse fator contribuiu para que muitas escolas técnicas-profissionalizantes privadas deixassem de ofertar essa modalidade de ensino a partir da segunda metade da década de 1980.

\subsubsection{O Colégio Marista de Cascavel no contexto do golpe militar de 1964}

A década de 1960 foi caracterizada por profundas mudanças no cenário políticoeconômico nos países da América Latina e desencadeou crises e conflitos ideológicos. O cenário internacional da Guerra Fria fez com que as crises e as tensões sociais aumentassem rapidamente. Esses e outros fatores, como o desenvolvimento e a modernização do capitalismo brasileiro, favoreceram para impedir que a classe operária conquistasse suas reivindicações. Foi nesse contexto de incertezas que a ação golpista foi desferida em $1^{\circ}$ de abril de 1964 no Brasil e o regime militar foi instaurado. Nas palavras de Amarilio Ferreira Junior e Marisa Bittar, esse regime político fez com que o processo de modernização do capitalismo acelerasse e consolidou a sociedade urbano-industrial brasileira depois do chamado "milagre econômico" entre os anos de 1969-1974 (FERREIRA Jr; BITTAR, 2008).

O regime militar, unido à burguesia nacional criou então, uma ditadura civil militar no país que perdurou até o ano de 1985. As forças políticas de oposição às ditaduras latinoamericanas foram denominadas pelos militares e pela burguesia nacional como "ameaça comunista". Esses, por sua vez, se organizaram com a criação da Operação Condor que tinha efetivo apoio dos EUA, que patrocinaram e articularam muitas das ações repressoras empreendidas pelas ditaduras latino-americanas. Instalada nos anos 1970, a Operação Condor buscava uma aliança político-militar entre as ditaduras militares da Argentina, Chile, Brasil, Bolívia, Paraguai e Uruguai. Os defensores dessa operação acreditavam que era necessário unir as forças contra o chamado "terrorismo internacional", representado pelos comunistas e pelos grupos opositores aos governos ditatoriais (COLARES, COLARES, 2003; FERREIRA Jr, BITTAR, 2008).

O Colégio Marista de Cascavel se situa nesta conjuntura histórica. Embora sua implantação tenha sido oficializada dois anos antes do regime militar, ele não somente teve de se adequar aos ditames do regime ditatorial, como cresceu amplamente após o golpe 
militar, que teve a aprovação dos Irmãos residentes em Cascavel, como consta dos Anais: "30 de março - Tudo corria normalmente, quando estourou a revolução democrática contra o nefasto governo de João Goulart. Foi uma verdadeira bênção de Deus para o Brasil" (COLÉGIO MARISTA DE CASCAVEL, 1962a). O discurso apresentado pelos Irmãos evidencia um posicionamento favorável à instauração do regime militar, chamado por eles de "Revolução Democrática".

No contexto da ditadura civil militar, o sistema educacional, como todas as demais instâncias da sociedade esteve sob o comando das forças armadas. Esse sistema político se utilizou de um discurso que apontava para a valorização da educação como um meio para atingir o sucesso da nação. Com isso, a educação passou a ser um instrumento utilizado pelos militares para obter hegemonia e, com característica tecnicista, auxiliar no crescimento econômico do país. Segundo Amarilio Ferreira Junior e Marisa Bittar:

[...] a política educacional do período entre 1964 e 1985 estava, em última instância, vinculada organicamente ao modelo econômico que acelerou, de forma autoritária, o processo de modernização do capitalismo brasileiro. Ainda mais: reformas educacionais que estavam inseridas num contexto histórico de transição de uma sociedade agrária para uma sociedade urbano-industrial, cujas transformações societárias se desenrolavam desde 1930 (FERREIRA Jr; BITTAR, 2008, p. 336).

De acordo com a proposta do Governo, educação e economia relacionavam-se diretamente. A educação foi condicionada pela lógica que determinava o crescimento econômico da sociedade capitalista e da industrialização. Esse foi um decisivo fator que contribuiu com o contexto de expansão e de acelerada urbanização de Cascavel e que justifica a implantação e o rápido desenvolvimento do Colégio Marista nesse município.

\subsubsection{O Colégio Comercial Marista de Cascavel}

O Colégio Comercial Marista de Cascavel foi fundado no mesmo ano em que o Ginásio Marista foi criado na cidade, 1962. À época não havia outra instituição educativa na cidade que ofertasse essa modalidade de ensino. Os Irmãos Maristas dispunham de estrutura material adequada para iniciar suas atividades na cidade com o Colégio Comercial, anexo ao Ginásio, mesmo sem legislação específica.

Para estabelecer um Curso Comercial, ou qualquer outro de caráter técnicoprofissional, antes mesmo da Lei 5.692/71, era necessária uma autorização para funcionamento. No ano de 1957, a Escola Técnica de Comércio Rio Branco, anexa ao Ginásio Rio Branco, recebeu do Ministério da Educação e Cultura a autorização para ofertar os cursos: Comercial Básico e Técnico de Contabilidade. Após os trâmites de negociação entre a administração do município e o Sr. Antonio Cid, proprietário da Escola Técnica de Comércio Rio Branco, foi passado os direitos à ABEC, mantenedora Marista, com o nome inicial de Colégio Comercial Marista de Cascavel (COLÉGIO MARISTA DE CASCAVEL, 1957; COLÉGIO MARISTA DE CASCAVEL, 1962b).

O Ginásio Marista de Cascavel continuou suas atividades relativas ao Ensino Técnico-profissional tendo sua primeira turma com o curso Colegial de Contabilidade Comercial, segunda consta do Regimento Interno de 1962, aprovado em 1964 (REGIMENTO INTERNO DO COLÉGIO MARISTA DE CASCAVEL, 1964). No ano de 1975, mediante Parecer 010/75, Processo nº 012/75 de 6 de fevereiro 1975, já com aprovação da LDB 5.692/71, lei que regulamentou o Ensino Profissionalizante no país, o 
Colégio Comercial Marista de Cascavel foi reformulado e, recebeu a aprovação, pelo Conselho Estadual de Educação do Paraná, do projeto de implantação de $2^{\circ}$ Grau, nas habilitações de Secretariado e Técnico de Contabilidade, para início em 1975, e de Estatística e Assistente de Administração, para início em 1976 (BRASIL, 1971; COLÉGIO MARISTA DE CASCAVEL, 1975).

Em 1982, mediante Resolução no $3.05 / 82$ de $1^{\circ}$ de fevereiro de 1982, foi autorizado o funcionamento do Curso Técnico para as habilitações plenas em Contabilidade e Assistente de Administração e parciais Auxiliar de Escritório Técnico de Edificações e Auxiliar de Patologia Clínica (COLÉGIO MARISTA DE CASCAVEL, 1982). O Ensino Técnico Profissionalizante foi, então, ofertado do seguinte modo:

a) Como Escola Técnica de Comércio Rio Branco, ofertou o Comercial Básico de 1957 a 1961 [Portaria 133/57; Portaria 514/59], e Técnico em Contabilidade de 1957 a 1959 [Portaria 133/57].

b) Como Colégio Comercial Marista de Cascavel, ofertou o curso Técnico em Contabilidade de 1962 a 1976 [Lei no 4024/61].

c) Como Colégio Marista de Cascavel, ofertou Habilitação Plena de Contabilidade de 1975 a 1976 e Habilitação Plena de Secretariado [Parecer no 010/75].

d) Como Colégio Marista - Ensino de $1^{\circ}$ e $2^{\circ}$ Graus, ofertou Habilitação Plena de Secretariado de 1977 a 1979, Habilitação Plena de Assistente de Administração de 1978 a 1982, Habilitação Plena de Contabilidade de 1977 a 1983 e Habilitação Parcial de Auxiliar de Patologia Clínica de 1979 a 1983 [Lei no 5692/71].

e) Como Colégio Marista - Ensino Pré-Escolar e de $1^{\circ}$ e $2^{\circ}$ Graus, ofertou Habilitação Plena de Contabilidade de 1984 a 1989, Habilitação Parcial de Auxiliar de Escritório Técnico de Edificações de 1979 a 1983 e Habilitação Parcial de Auxiliar de Patologia Clínica em 1984 (Lei no 5692/71).

O Colégio Marista cessou as atividades de modalidade Técnico-Profissionalizante a partir da segunda metade da década de 1980. O primeiro curso a ser extinto foi o de Secretariado, encerrando suas atividades no ano de 1979, antes mesmo de entrar em vigor a Deliberação n⿳030/80 do Conselho Estadual de Educação-CEE. O curso de Assistente de Administração deixou de existir, mediante Resolução n ${ }^{\circ}$ 2.155/84 da Secretaria de Estado da Educação-SEED, em 27 de abril de 1984 (COLÉGIO MARISTA DE CASCAVEL, 1984a). Os cursos de Auxiliar de Patologia Clínica e Auxiliar de Escritório Técnico de Edificações foram extintos no ano de 1984 por Resolução 8.96/84 da Secretaria de Estado da Educação-SEED, de 16 de março 1984 (COLÉGIO MARISTA DE CASCAVEL, 1984b). O curso de Contabilidade cessou suas atividades em 1989 mediante Resolução ${ }^{\circ}$ 2.726/89 da Secretaria de Estado da Educação-SEED (COLÉGIO MARISTA DE CASCAVEL, 1989).

Diante desses fatos, podemos dizer que a formação para o trabalho estava presente na educação brasileira antes mesmo de haver uma legislação educacional específica para essa modalidade. No caso de Cascavel, à época uma cidade pouco escolarizada, ter a modalidade de Ensino Técnico-Profissionalizante, representou a preocupação dos responsáveis pela administração do município, de que a especialização para o trabalho tornaria a economia local mais sólida.

A partir das análises entendemos que a organização pedagógica, as práticas educativas, o currículo, os programas, os conteúdos, o prédio, os exames, o desporto e a disciplina revelam que o Colégio Marista de Cascavel, quando de sua implantação, teve o objetivo de distinguir, pela cultura letrada, um determinado grupo social, a pioneira elite cascavelense. 


\section{Conclusão}

A reconstituição histórica da origem e do desenvolvimento do Colégio Marista de Cascavel permitiu indicar para algumas conclusões que serviram de subsídios para o estudo da questão educacional de Cascavel, da região oeste do Paraná e do contexto educacional brasileiro. A pedagogia Marista se constituiu num importante instrumento para a análise do processo educativo do período analisado. Ao estudarmos a história dessa instituição escolar, foi possível reconhecer sua identidade institucional católica.

Constatamos por meio desta investigação que o Colégio Marista de Cascavel ofereceu uma modalidade de ensino de caráter técnico-profissional, isso se constituiu numa importante particularidade, pois o município, naquele período, passava por um processo de urbanização que exigia mão de obra qualificada para atender à nova demanda de trabalho urbano.

O Colégio Marista possui uma importante trajetória histórica, social e cultural em Cascavel e região e, desde a sua implantação, há mais de cinquenta anos, visou formar, por meio de uma pedagogia cristã, indivíduos que fossem bons cristãos e virtuosos cidadãos e que estivessem aptos para o mercado de trabalho, a fim de fomentar a economia local, tornando-a mais sólida.

Após o levantamento, catalogação e análise das fontes, constatamos que a história desta instituição educativa está imbricada com a própria história do surgimento da cidade. O Colégio foi criado para atender um público específico, ou seja, era voltado para a formação da elite pioneira cascavelense. A escola apresentou-se como opção educacional àquela sociedade, pois se constituía numa alternativa de estudo diferenciada, com uma proposta pedagógica que atendia às exigências políticas, econômicas e sociais da época. $\mathrm{O}$ Colégio Marista acompanhou o processo de crescimento e desenvolvimento da cidade de Cascavel. No decorrer dos anos, houve evolução em suas propostas de ensino e em sua infraestrutura.

O Colégio Marista de Cascavel primou por uma educação integral, isto é, uma educação que compreendia o físico, a mente e o espírito; com um ensino de caráter moral, civil e religioso, quer fosse por meio da educação física, da instrução patriótica, da educação religiosa, da educação escolarizada ou da disciplina. Na pedagogia Marista aplicada no Colégio de Cascavel, predominou os preceitos e valores do catolicismo, conforme proposto pela hierarquia da Igreja Católica Romana no período pós Concílio Vaticano II.

A pesquisa mostrou que a instituição exerceu, especialmente em seus primeiros anos de funcionamento, um importante papel no conjunto das relações sociais, sempre ao lado dos grupos que detinham o poder ou exerciam significativa influência sobre a sociedade. Poucos tinham acesso aos estudos e menor ainda era o número de pessoas que poderiam pagar os estudos naquela escola, mesmo assim, os documentos e depoimentos recolhidos pela pesquisa mostram que ela é sempre representada como formadora da elite regional, com formação adequada para a ocupação de postos no comando político regional.

O Colégio Marista de Cascavel se firmou na cidade como uma instituição de qualidade, que se ocupou em oferecer uma educação voltada para a formação integral (moral, civil e religiosa) do indivíduo. Os Irmãos Maristas que atuaram na cidade souberam adaptar sua proposta educacional às necessidades da elite regional, que se preocupava em ver seus filhos atuantes na sociedade, com um ensino voltado para a formação do caráter de um bom cristão e cidadão, cuja finalidade era utilizar a prática educativa como um meio para cristianizar a sociedade local, sua cultura, hábitos e costumes, para então, contribuir com o processo de crescimento e urbanização do 
munícipio. Portanto, o Colégio Marista cumpriu sua função educacional e social na cidade de Cascavel

\section{Referências}

\section{Fontes Primárias}

CASCAVEL. Lei $\mathrm{N}^{\circ}$ 292/64 de 14 de setembro de 1964 que autoriza a transferência do terreno à ABEC. Cascavel, [Arquivo do Colégio Marista de Cascavel], 1964.

COLÉGIO MARISTA DE CASCAVEL. Anais do Colégio Marista de Cascavel. Cascavel, [Arquivo do Colégio Marista de Cascavel], 1962a.

COLÉGIO MARISTA DE CASCAVEL. Histórico. Cascavel, [Arquivo do Colégio Marista de Cascavel], 1962b.

COLÉGIO MARISTA DE CASCAVEL. Resolução de cessação de atividades 2155/84 da Secretaria de Estado da Educação-SEED, em 27 de abril de 1984a.

COLÉGIO MARISTA DE CASCAVEL. Resolução de cessação de atividades 896/84 da Secretaria de Estado da Educação-SEED, de 16 de mar. 1984b.

COLÉGIO MARISTA DE CASCAVEL. Resolução de cessação de atividades 2.726/89 da Secretaria de Estado da Educação-SEED, 1989. COLÉGIO MARISTA DE CASCAVEL. Aprovação de projeto de implantação. Parecer 010/75; Processo no 012/75 de 06 de fev. 1975, Conselho Estadual de Educação.

COLÉGIO MARISTA DE CASCAVEL. Autorização de funcionamento. Resolução ${ }^{\circ}$ 305/82 de 17 de fev. 1982, Secretaria de Estado da Educação.

COLÉGIO MARISTA DE CASCAVEL. Revista Marista: lutas e conquistas. Edição especial comemorativa aos 30 anos de fundação, 2003.

COLÉGIO MARISTA DE CASCAVEL. Autorização de funcionamento. Portaria ${ }^{\circ} 133$ de 12 de mar. 1957, MEC.

COLÉGIO MARISTA DE CASCAVEL. Regimento interno do Colégio Marista de Cascavel. Cascavel, 1964.

CURITIBA, Diário Oficial Estado do Paraná. Divisão administrativa do Estado no quinquênio de 1952 a 1956. LEI $n^{\circ}$ 790/51. Curitiba, 1951.

FAUTH, Elio Willy. Tudo sobre Cascavel: história, comércio, indústria, poder público, entidades, informações, estatísticas. $2^{a}$ ed. Cascavel, 1973. 


\section{Literatura de Apoio}

ARNAUT DE TOLEDO, Cézar de Alencar; ANDRADE, Rodrigo Pinto de. História e historiografia da Escola Lutera Concórdia de Marechal Cândido Rondon (1955-1969). In: SILVA, João Carlos da, ORSO, José Paulino, CASTANHA, André Paulo, MAGALHÃES, Lívia Diana Rocha (Org.). História da Educação: arquivos, instituições escolares e memória histórica. Campinas: Alínea, 2013. p. 191-210.

ARNAUT DE TOLEDO, Cézar de Alencar; ANDRADE, Rodrigo Pinto de. História da educação, instituições escolares, fontes e pesquisa em arquivos na região oeste do Paraná. Revista Linhas. Florianópolis, v. 15, n. 28, p. 175-199, jan./jun. 2014.

BESKOW, Gabriela Carames. Marchando para Oeste - discursos sobre as políticas varguistas de integração nacional. ANPUH-XXIV Simpósio Nacional de História - São Leopoldo, 2007. Disponível em: <http://anpuh.org/anais/wp-

content/uploads/mp/pdf/ANPUH.S24.0510.pdf> Acesso em: 24 set. 2016.

BITTAR, Marisa; FERREIRA JUNIOR, Amarilio. História, epistemologia marxista e pesquisa educacional brasileira. Educação \& Sociedade. Campinas, v. 30, n. 107, p. 489$511,2009$.

BÔAS, Orlando Villas; BÔAS, Cláudio Villas. A marcha para o Oeste. 4 ed. São Paulo: Globo, 1994.

BUFFA, Ester. História e filosofia das instituições escolares. In: ARAÚJO, José Carlos; GATTI JÚNIOR, Décio. (Org.) Novos temas em história da educação brasileira: instituições escolares e educação na imprensa. Campinas: Autores Associados: Uberlândia: EDUFU, 2002. p. 25-38.

BRASIL. Lei n. 4.024, de 20 de dezembro de 1961. Fixa as Diretrizes e Bases da educação nacional. Lex: Coletânea de legislação e Jurisprudência. São Paulo, v.25, p. 979-993, 1961.

BRASIL. Decreto-Lei n. 4.244 de 9 de abril de 1942. Lei orgânica do Ensino

Secundário. Coletânea de legislação e Jurisprudência. São Paulo, v.6, p. 179-194, 1942.

BRASIL. Lei n. 5.692, de 11 de agosto de 1971. Fixa Diretrizes e Bases para o ensino de $1^{\circ}$ e $2^{\circ}$ graus, e dá outras providências. Lex: Coletânea de legislação e Jurisprudência. São Paulo, v.35, p. 1114-1125, 1971.

CAPELO, Maria Regina Clivati. Educação, Escola e Diversidade Cultural no meio rural de Londrina: quando o presente reconta o passado. 2000. 287f. Tese (Doutorado em Educação, Sociedade e Cultura) - Universidade Estadual de Campinas, Campinas, 2000.

COLARES, Anselmo Alencar; COLARES, Maria Lília Imbiriba Souza. Do autoritarismo repressivo à construção da democracia participativa. Campinas: Autores Associados, 2003. 
COLODEL, José Augusto. Cinco Séculos de História. In: PERIS, Alfredo Fonceca. (Org.). Estratégias de desenvolvimento regional: Região Oeste do Paraná. Cascavel: EDUNIOESTE, 2003, 536 p.

CURY, Carlos Roberto Jamil. Educação e contradição: elementos metodológicos para uma teoria crítica do fenômeno educativo. São Paulo: Cortez, 1985.

CURY, Carlos Roberto Jamil. Ideologia e Educação Brasileira: Católicos e liberais. 4 ed. São Paulo: Cortez ; Autores Associados, 1988.

EMER, Ivo Oss. Desenvolvimento histórico do oeste do Paraná e a construção da escola. Dissertação de Mestrado. 1991. 339 f. Dissertação (Mestrado em Educação). Instituto de Estudos Avançados em Educação, Fundação Getúlio Vargas, Rio de Janeiro, 1991.

EMER, Ivo Oss. Aspectos históricos da educação regional. Cascavel, 2004. Mímeo.

EMER, Ivo Oss. Um pouco da história da educação no oeste do paraná. Revista HISTEDBR On-line, Campinas, número especial, p. 34-48, mai/2012. Acesso em: 10 agos. 2013.

FERREIRA JUNIOR, Amarilio; BITTAR, Marisa. Educação e ideologia tecnocrática na ditadura militar. Cadernos CEDES, Campinas, v. 28, n. 76, p. 333-355, set./dez., 2008.

GARUTI DE ANDRADE, Francielle Aparecida. O Colégio Marista no contexto da urbanização de Cascavel (1962-1989). 2016. 386 f. Dissertação (Mestrado em Educação). Programa de Pós-Graduação em Educação, Universidade Estadual de Maringá, 2016.

GATTI JÚNIOR, Décio. História e historiografia das instituições escolares: percursos de pesquisa e questões teórico-metodológicas. Revista Educação em Questão, Natal, v. 28, n. 14, p. 172-191, jan./jun. 2007.

GOHN, Maria da Glória Marcondes. A pesquisa na produção do conhecimento: questões metodológicas. EccoS - Revista Científica, São Paulo, v. 7, n. 2, p. 253-274, jul./dez. 2005.

GRONDIN, Marcelo. Alvorecer de Toledo, na colonização do Oeste do Paraná-1946 49. Marechal Cândido Rondon: Editora Germânica, 2007.

LENHARO, Alcir. Sacralização da Política. São Paulo: Papirus, 1986.

MAGALHÃES, Justino Pereira de. Contributo para a História das Instituições

Educativas: Entre a Memória e o Arquivo. Braga, Universidade do Minho, 1999.

MAGALHÃES, Justino Pereira de. Da cadeira ao banco: escola e modernização (séculos XVIII-XX). Lisboa: EDUCA, 2010.

MARX, Karl. O Método da Economia Política. 3a Parte. In: Introdução à Crítica da Economia política. Tradução de Fausto Castilho. Campinas: IFCH/Unicamp, 1996. 
MARX, Karl. Contribuição à crítica da economia política. São Paulo: Martins Fontes, 1983.

MOURA, Pe. Laércio Dias de. A educação católica no Brasil. São Paulo: Edições Loyola, 2000.

NATH, Valdecir Antonio. História e Memória: A constituição histórica da Rede Municipal de Ensino de Cascavel (1950 A 1980). 2010. 118 f. Monografia (Especialista em História da Educação Brasileira). Universidade Estadual do Oeste do Paraná, Cascavel, 2010 .

NATH, Valdecir Antonio. A primeira escola secundária pública de Cascavel: O Ginásio Wilson Joffre (1960-1980). 2013. 150 f. Dissertação (Mestrado em Educação). Programa de Pós-Graduação em Educação, Universidade Estadual do Oeste do Paraná, Cascavel, 2013.

NETTO, José Paulo. Introdução ao método da teoria social. In: Serviço social: direitos sociais e competências profissionais. Brasília: CFEES/ABEPSS, 2009.

NOSELLA, Paolo; BUFFA, Ester. As pesquisas sobre instituições escolares: o método dialético marxista de investigação. In: ARAUJO, Ronaldo Marcos de Lima; RODRIGUES, Doriedson (Org.). Trabalho, educação e políticas educacionais. Campinas: Alínea, 2012. p.131- 146.

NOSELLA, Paolo; BUFFA, Ester. Instituições Escolares: por que e como pesquisar. Campinas: Alínea, 2009.

PIAIA, Vander. A ocupação do Oeste Paranaense e a formação de Cascavel: as singularidades de uma cidade comum. 2004. 213 f. Tese (Doutorado em História). Programa de Pós-Graduação em História, Universidade Federal Fluminense. Niterói, 2004.

PIAIA, Vander. Terra, sangue e ambição: a gênese de Cascavel. Cascavel: EDUNIOESTE, 2013.

REOLON, Cleverson Alexsander. A aglomeração urbana da soja: Cascavel e Toledo no contexto da metropolização na Mesorregião oeste paranaense. 2007. 244 f. Dissertação (Mestrado em Desenvolvimento Regional e Agronegócio). Programa de Pós-Graduação em Desenvolvimento Regional e Agronegócio, Universidade Estadual do Oeste do Paraná Toledo, 2007.

SANFELICE, José Luís. História das Instituições Escolares. In: NASCIMENTO, Maria Isabel Moura: SANDANO, Wilson; LOMBARDI, José Claudinei; SAVIANI, Dermeval (Org.). Instituições Escolares no Brasil: conceito e reconstrução histórica. Campinas: Autores Associados, 2007. p. 75-93.

SANFELICE, José Luís. História, instituições escolares e gestores educacionais. Revista HISTEDBR On-line, Campinas, n. especial, p.20-27, ago. 2006. 
SANFELICE, José Luís. História de instituições escolares e micro história. Revista HISTEDBR On-line, Campinas, n.39, p. 32-41, set.2010.

SANFELICE, José Luís. História e historiografia de instituições escolares. Revista HISTEDBR On-line, Campinas, n.35, p. 192-200, set.2009. Disponível em: <www. histedbr.fae.unicamp.br/revista/edicoes/35/art13_35.pdf>. Acesso em: 10 ago. 2015.

SANFELICE, José Luís. História de instituições escolares: apontamentos preliminares. Revista HISTEDBR On-line, Campinas, n.08, out. 2002. Disponível em: <www. histedbr.fae.unicamp.br/revista/edicoes/35/art13_35.pdf>. Acesso em: 24 set. 2016.

SAVIANI, Dermeval. Educação: do senso comum à consciência filosófica, São Paulo: Cortez, 1983.

SAVIANI, Dermeval. Instituições Escolares no Brasil Conceito e Reconstrução Histórica. In: NASCIMENTO, Maria Isabel Moura; SANDANO, Wilson; LOMBARDI, José Claudinei; SAVIANI, Dermeval (Org.). Instituições Escolares no Brasil: conceito e reconstrução histórica. Campinas: Autores Associados, 2007. p. 03-27.

SAVIANI, Dermeval. Aberturas para a história da educação: do debate teóricometodológico no campo da história ao debate sobre a construção do sistema nacional de educação no Brasil. Campinas: Autores Associados, 2013.

SAVIANI, Dermeval. História das Ideias Pedagógicas no Brasil. 2. Ed. rev. e ampl. Campinas: Autores Associados, 2008.

SBARDELOTTO, Denise Kloeckner. O desenvolvimento dos cursos de formação de professores primários na fronteira oeste paranaense: a criação da primeira Escola Normal Secundária pública de Foz do Iguaçu e do Oeste do Paraná. 2009. 212 f. Dissertação (Mestrado em Educação). Programa de Pós-Graduação em Educação, Universidade Estadual de Ponta Grossa, Ponta Grossa, 2009.

SPERANÇA, Alceu. Cascavel a história. Curitiba: Lagarto, 1992.

SPERANÇA, Alceu. Jornal o Paraná, janeiro de 2006.

SPERANÇA, Alceu; SPERANÇA, Carlos. Pequena história de Cascavel e do Oeste. Cascavel: J. S. Impressora. 1980.

THOMÉ, Sérgio Antonio. A primeira escola primária em Cascavel. 2005. $71 \mathrm{f}$. Monografia (Especialista em História da Educação Brasileira). Universidade Estadual do Oeste do Paraná, Cascavel, 2005.

TREVISAN, Albino. Respiga Marista: educação e ação social marista no Rio Grande do Sul. Porto Alegre: EDIPUCRS, 2009.

VIEIRA, Dilermando Ramos. O processo de reforma e reorganização da Igreja no Brasil (1844-1926). Aparecida, SP: Santuário, 2007. 
WACHOWICZ. Obrageros, mensus e colonos: história do oeste paranaense. Curitiba: Vicentina, 1982.

XAVIER, Maria Elizabete Sampaio Prado; RIBEIRO, Maria Luísa Santos; NORONHA, Olinda Maria. História da Educação: a escola no Brasil. São Paulo: FTD, 1994.

\footnotetext{
${ }^{1}$ Mestre em Educação pela Universidade Estadual de Maringá com graduação em História pela mesma instituição. Possui especialização em Literatura Brasileira e Inglesa e graduação em Letras pela Universidade Estadual do Paraná e graduação em Pedagogia pela Universidade Nove de Julho. Direção eletrônica: garuti_andrade@yahoo.com.br

${ }^{2}$ Doutor em Educação pela Unicamp (1996), professor do Departamento de Fundamentos da Educação e do Programa de Pós-Graduação em Educação da Universidade Estadual de Maringá, Mestrado e Doutorado. Direção eletrônica: caatoledo@uem.br

${ }^{3}$ As obrages nada mais foram do que imensos domínios rurais que se estabeleceram, primeiro no norte argentino e, posteriormente, no oeste do Paraná e na parte sul do Estado do Mato Grosso para a exploração da erva-mate e da madeira, empregando, geralmente, mão-de-obra paraguaia, denominada "mensus", em sistema de quase escravidão (GRONDIN, 2007, p. 41).

${ }^{4}$ A Casa Escolar era mantida pelo Poder Público e possuía apenas duas salas de aula. Nesse tipo de estabelecimento de ensino funcionavam turmas de $1^{\text {a }}$ a $3^{\text {a }}$ série num modelo de classe multisseriada, que, correspondia à junção de várias séries em uma única classe. Nesse modelo, o professor dividia o quadro em quantas partes fossem necessárias para atender às séries existentes nas classes (CAPELO, 2000).

${ }^{5}$ Casa Escolar Pública era um formato educacional oficializado pelo poder público, que era o responsável pela sua construção e pela remuneração dos professores. Nesse formato, os alunos eram submetidos a exames elaborados pelos órgãos educacionais competentes para que confirmassem a escolarização realizada no nível do ensino primário. Uma vez aprovado, o aluno receberia um certificado de conclusão, que poderia contribuir para conquista de espaço social, no contexto da já ampla divisão do trabalho (EMER, 2004).

${ }^{6}$ A implantação dos grupos escolares no Paraná ocorreu a partir de 1903, quando foi instalado o primeiro grupo escolar na cidade de Curitiba; mas, a regulamentação dos grupos escolares no estado só aconteceu em 1914, com a Portaria n. ${ }^{\circ}$ 4- D.O. 17.1.14/4 n. ${ }^{\circ}$ 574, de 30 de janeiro de 1914. Os grupos escolares estavam localizados nos principais centros urbanos e estavam voltados para o ensino em quatro séries, com conteúdos progressivos, sob a responsabilidade de um professor em cada série e coordenados por um diretor de grupo. Esse formato de ensino foi instituído no contexto da urbanização dos municípios que exigiam mais investimentos na área da educação (SOUZA, 2004; EMER, 2012).

${ }^{7}$ Os Anais estão registrados em dois volumes, o $1^{\circ}$ volume consta do ano de 1962 até o ano de 1986; o $2^{\circ}$ volume não foi encontrado nas dependências do Colégio, portanto não sabemos precisar o ano do término dos registros.

${ }^{8}$ A partir do ano de 1973 a nova LDB 5692/71 foi implantada em todas as séries. Após esse ano, novos cursos foram abertos e foi iniciada a construção do novo prédio do Colégio Marista de Cascavel, inaugurado no dia 11 de outubro de 1975. O novo prédio era mais moderno, projetado para acompanhar o crescimento da cidade; entre as novas instalações constavam o laboratório de biologia, física e química, a biblioteca, áreas esportivas e um parquinho.

9 A partir de 1973 novos cursos foram abertos. Pela Resolução n ${ }^{\circ}$ 1583/03 - D.O.E de 16 de jul. 2003, o estabelecimento passou oficialmente a denominar-se: Colégio Marista de Cascavel - Educação Infantil, Ensino Fundamental e Médio.
}

Recebido: abril-16 Aprovado: setembro-16 